\title{
Why is there no discipline of technology in the social sciences?
}

Pourquoi la technologie n'est-elle pas une discipline dans les sciences sociales?

\section{Eric Schatzberg}

\section{(2) OpenEdition}

\section{Journals}

Electronic version

URL: http://journals.openedition.org/artefact/2150

DOI: $10.4000 /$ artefact. 2150

ISSN: 2606-9245

Publisher:

Association Artefact. Techniques histoire et sciences humaines, Presses universitaires du Midi

\section{Printed version}

Date of publication: 6 December 2018

Number of pages: 193-213

ISBN: 978-2-8107-0595-5

ISSN: 2273-0753

\section{Electronic reference}

Eric Schatzberg, «Why is there no discipline of technology in the social sciences? 》, Artefact [Online], 8 | 2018, Online since 21 June 2019, connection on 28 November 2020. URL : http:// journals.openedition.org/artefact/2150 ; DOI : https://doi.org/10.4000/artefact.2150

\section{(c) $(1) \odot$}

Artefact, Techniques, histoire et sciences humaines est mise à disposition selon les termes de la Licence Creative Commons Attribution - Pas d'Utilisation Commerciale - Pas de Modification 4.0 International. 


\section{Why is there no discipline of technology in the social sciences?}

\section{Eric Schatzberg}

\section{Abstract}

In this paper, I try to understand why no major field of technology ever emerged in the English-language social sciences, using $19^{\text {th }}$ century anthropology as a case study. According to etymology, technology should refer to a logos, a field of study or discourse, about techne, technical knowledge and practice. Yet no such general field exists. Instead, during first half of the $20^{\text {th }}$ century, the English term technology lost its earlier meaning as a field of study, becoming roughly equivalent to the $19^{\text {th }}$ century term industrial arts. In this sense, technology is clearly a form of human activity that should fall under the purview of the social sciences. But technology does not exist as an established field of study in any social science, even under another name. At the end of the $19^{\text {th }}$ century, however, technology was proposed as one of the core fields in the emerging field of anthropology by John Wesley Powell, one of the founders of the discipline in the United States. Yet Franz Boas, a young German scholar who had recently moved to the United States, argued against this focus on technology, in part because of its links to the dominant evolutionary paradigm, which Boas opposed. Similar stories can be culled from the history of other social sciences, such as economics and sociology. What accounts for this pattern? Although no single explanation suffices, this pattern is rooted in the deeply ingrained prejudice among intellectuals that favors works of the mind over works of the hand, and theory over practice.

\section{Keywords}

technology, conceptual history, anthropology, discipline formation

99 Eric Schatzberg, « Why is there no discipline of technology in the social sciences? », Artefact, 8, 2018, p. 193-213. 


\section{Pourquoi la technologie n'est-elle pas une discipline dans les sciences sociales?}

\section{Résumé}

Dans ce texte, j'essaie de comprendre pourquoi aucun champ disciplinaire de la technologie n'a émergé dans les sciences sociales anglophones, en prenant l'anthropologie du xix siècle comme cas d'étude. D’après l'étymologie, la technologie devrait signifier le logos, c'est-à-dire, la science ou le discours sur la techne, les connaissances et pratiques techniques. Pourtant, aucun champ disciplinaire de ce genre n'existe. En lieu et place, durant la première moitié du $x x^{e}$ siècle, le terme anglais technology perd son premier sens de champ disciplinaire et devient à peu près l'équivalent de l'expression arts industriels du xIx $x^{e}$ siècle. En ce sens, la technologie est alors une forme d'activité que doivent prendre en charge les sciences sociales, même sous une autre dénomination. Cependant, à la fin du XIX $x^{\mathrm{e}}$ siècle, la technologie fut proposée comme l'un des points centraux de l'anthropologie en plein essor par John Wesley Powell, l'un des fondateurs de cette discipline aux États-Unis, alors que Franz Boas, un jeune universitaire allemand récemment arrivé aux États-Unis, s'élevait contre cette importance donnée à la technologie, en raison notamment des liens de celle-ci avec le paradigme évolutionniste dominant, auquel Boas était opposé. Des observations comparables peuvent être tirées de l'histoire d'autres sciences sociales comme l'économie ou la sociologie. Il n'y a pas d'explication unique, car cette tendance est profondément enracinée parmi les intellectuels qui donnent la priorité aux œuvres de l'esprit sur celles de la main, et à la théorie sur la pratique.

\section{Mots-clés}

technologie, histoire intellectuelle, anthropologie, formation disciplinaire 


\section{Introduction}

Technology has never existed as a major scholarly discipline, either as a technical or social-scientific field. This absence is surprising, because $19^{\text {th }}$ century dictionaries almost universally defined technology as the science of the arts, or at times more precisely as "the science or systematic knowledge of the industrial arts." ${ }^{1}$ This definition accords with etymology, with techno$\log y$ as the logos of techne, a discipline devoted to the study of the useful arts.

But this definition of technology as the science of the arts never translated into any organized domain of scholarly knowledge, at least not using this term. To be sure, many present-day academic fields focus on technical subjects, and some disciplines even have technology in their names, such as "information technology." But there is no scholarly organization that embraces technology as a field of knowledge, no national societies for the advancement of technology, and no academies of technology. ${ }^{2}$ Although my focus here is on scholarship in English, I believe that a similar case about the absence of technology as a scholarly discipline can be made regarding cognates of term in other European languages.

Rather than designating a robust academic field, the English term techno$\log y$ in effect lost its logos, its meaning as a field of knowledge or an area of study. As I have argued elsewhere, technology gradually shed this older meaning in the early $20^{\text {th }}$ century. This shift occurred when American social scientists imposed a new set of meanings on technology, meanings they drew from the German discourse of Technik. In this discourse, Technik referred to the methods, tools, and instruments used to create and maintain material culture, what in English at the time was termed industrial arts. ${ }^{3}$ This industrial-arts meaning remains at the core of the present-day concept of technology.

1. William Dwight Whitney (ed.), The Century Dictionary: A Work of Universal Reference in All Departments of Knowledge, $2^{\text {nd }}$ ed., 13 vols., vol. 8, New York, Century Co., 1897, p. 390.

2. Admittedly some organizations include technology in their name, starting with the Massachusetts Institute of Technology, chartered in 1860. But MIT never made technology into a scholarly discipline. See Julius Adams Stratton and Loretta H. Mannix, Mind and Hand: The Birth of MIT, Cambridge, Mass., MIT Press, 2005.

3. Eric SchatzBerg, "Technik Comes to America: Changing Meanings of Technology before 1930", Technology and Culture, 47, 2006, p. 486-512. 
Yet this change in meaning does not really explain why technology never become a major discipline, especially in social sciences. There can be no technology without people. When used in the sense of industrial arts, technology is after all, a form of art, and there can no art without an artist. Understood in this way, technology clearly belongs as much to the social as to the natural sciences. Yet there are no major subfields within the social sciences devoted primarily to this topic. When technology is the object of social-scientific interest, it is usually in the compound phrase science and technology, which really is a shorthand meaning "science and its applications." 4

Anglophone scholars of technology, whether historians, sociologists, or philosophers, repeatedly lament their marginal status in the academy. This marginality is related to a point that Bruno Latour has made repeatedly, that sociologists (which I think for him means social scientists in general) systematically exclude nonhumans from their theories. ${ }^{5}$ Like many of the Latour's sweeping claims, this one is easily refuted yet contains an element of truth. No social-science disciplines deny, as a matter of principle, a role for the biological processes of the human body, the physical constraints of the environment, or the tools and artifacts that have always been essential to human survival. Yet Latour is partly correct, because social sciences remain firmly anthropocentric, focusing on humans and their relationships, grudgingly acknowledging the essential materiality of human existence with a "yes, but..." and then returning their attention back to the immaterial aspects of social life. Even when scholars ostensibly embrace materiality, their discourse remains remote from the sensuous presence of materials themselves, as Tim Ingold has forcefully argued. ${ }^{6}$ In other words, despite accepting a key role for the material world in principle, social scientists have done little to theorize this role. ${ }^{7}$

In this paper, I try to understand why no major field of technology ever emerged in the English-language social sciences, using $19^{\text {th }}$ century

4. This asymmetry remains present even in contemporary science and technology studies, even though this field largely rejects the definition of technology as the application of science.

5. Bruno Latour, "Mixing humans and nonhumans together: the sociology of a door-closer", Social Problems, 35, 1988, p. 298-310.

6. Tim Ingold, "Materials against materiality", Archaeological Dialogues, 14, 2007, p. 1-16.

7. There are of course exceptions: The Perception of the Environment: Essays on Livelihood, Dwelling and Skill, London, New York, Routledge, 2000. 
anthropology as a case study. There are moments in the history of anthropology, sociology, and economics where a sustained theoretical discourse on technology seemed poised to emerge. Yet in every instance, scholars pulled back, either declaring the topic out of bounds or of no interest to the discipline.

Many opportunities for creating a discipline around the concept of techno$\log y$ in English arose in the $19^{\text {th }}$ and early $20^{\text {th }}$ centuries. These opportunities include Jacob Bigelow's Elements of Technology in 1829, George Wilson's position as the first (and last) Regius Professor of Technology at Edinburgh University from 1855 to 1859 , and the chartering of the Massachusetts Institute of Technology in 1860. Later opportunities include the John Wesley Powell's definition of technology as a subfield of anthropology, "the science of industry," in the late 1890s, and Thorstein Veblen's embrace of technology under the influence of Werner Sombart and Gustav Schmoller. ${ }^{8}$ This paper is, in a sense, about these missed opportunities.

Is it even legitimate to ask why the social sciences lack a discipline of technology? This question is a counterfactual, about something that did not happen. Such claims are usually considered out of bounds in history, although historians have actively discussed counterfactuals in the past few years. ${ }^{9}$ My query is reminiscent, on a small scale, of Joseph Needham's question of why the scientific revolution did not occur in China. One of Needham's collaborators, Nathan Sivin, once remarked that the Needham question was like asking why my name did not appear on the front page of the New York Times today. However, my question is quite different from the Needham question. The Needham question is about singular historical events, the scientific and industrial revolutions, which were exceptions in world history. ${ }^{10}$ Needham, for all his love of China, still posited the history

8. Jacob BigeLow, Elements of Technology: Taken Chiefly from a Course of Lectures Delivered at Cambridge, on the Application of the Sciences to the Useful Arts: Now Published for the Use of Seminaries and Students, Boston, Hilliard Gray Little and Wilkins, 1829; George Wilson, What is Technology? An Inangural Lecture Delivered in the University of Edinburgh, on November 7, 1855, Edinburgh, Sutherland and Knox, 1855; Julius Stratton and Loretta Mannix, Mind and Hand. The Birth of the MIT, Boston, The MIT Press, 2005 ; John W. Powell, "Technology, or the science of industries", American Anthropologist 1, n 2, 1899; E. Schatzberg, "Technik comes to America”, op. cit. 9. Richard J. Evans, Altered Pasts: Counterfactuals in History, Waltham, Massachusetts, Brandeis University Press/Historical Society of Israel, 2013.

10. Nathan Sivin, "Why the scientific revolution did not take place in China - or did it?", Environmentalist, 5, 1985, p. 39-50. 
of the West as the norm against which other countries needed to be measured. In contrast, the question of why technology did not become a socialscience discipline arises from the historical actors themselves, scholars who deployed technology and related categories in their research and writing. ${ }^{11}$

\section{Background: a brief history of the concept of technology}

The history of the concept of technology has been hobbled by the power of the present-day word. Many scholars treat technology as unproblematic, and they project present-day meanings onto the past. This tendency is well known among historians of concepts, and is to a certain extent unavoidable, because history always involves translation of past meanings into the present. Yet for reasons that I hope will become clear by the end of this essay, technology remains one of the least examined among the core concepts of late modernity.

A quick survey of the term's history demonstrates its problematic character. The Latin term technologia was an early modern neologism. It had no importance in ancient Greece and Latin in its modern sense. The term was present in Roman and Byzantine Greek as a word referring to grammar, that is, the techne of logos, not the logos of techne. ${ }^{12}$ When the term reemerged in the $16^{\text {th }}$ century in the work of Peter Ramus, it referred to a taxonomy of the arts or the study of the arts. For Ramus, technologia was a system of classification covering all arts, although he focused on the liberal arts. Only in late $17^{\text {th }}$ and early $18^{\text {th }}$ centuries did term come to mean the science or study of the mechanical arts. For example, in the 1661 edition of Blount's Glossographia, a dictionary of "Hard Words," technology was defined as a term of Greek origin signifying "a treating or description

11. On discipline formation, see Peter Weingart, "A short history of knowledge formations", in Robert Frodeman, Julie Thompson Klein and Carl Mitcham (ed.), The Oxford handbook of interdisciplinarity, Oxford, Oxford University Press, 2010, p. 3-14.

12. Edmund O. von Lippmann, Beiträge zur Geschichte der Naturwissenschaften und der Technik?, Berlin, Springer, 1923, p. 199-201; Carl Mrтснам, Thinking Through Technology: The Path Between Engineering and Philosophy, Chicago, University of Chicago Press, 1994, p. 128-130. 
of Crafts, Arts or Workmanship." ${ }^{13}$ But this term remained rare in any European language into the $19^{\text {th }}$ century.

In medieval and early modern Europe, the closest equivalent to the modern idea of technology was mechanical arts (artes mechanicae). This phrase was a medieval innovation, a category that encompassed crafts and other types of productive knowledge, often organized into seven mechanical arts to parallel the seven liberal arts. The mechanical arts emerged as a new category rooted in Christian ideas about manual labor. Medieval Christian scholars had a somewhat more positive view of manual labor than Roman writers, but Christian attitudes toward labor and crafts remained profoundly ambivalent. ${ }^{14}$ Medieval scholars never accorded the mechanical arts the systematic treatment given to more suitably theological topics.

The rise of the new experimental philosophy of the $17^{\text {th }}$ century provided another missed opportunity for theoretical engagement with the mechanical arts, especially given Francis Bacon's stress on practical applications ("works"). The new philosophy did indeed contain much praise of the mechanical arts. Yet as Peter Dear has noted, natural philosophers placed themselves in an awkward position when they praised arts that were practiced by men of inferior social status, that is, artisans. Scholarly elites did not embrace an alliance of equals between artisans and philosophers. Instead, says Dear, advocates of the mechanical philosophy "set themselves up as prophets of a kind of value-added practical knowledge wherein the untutored artisan would be disciplined by the literate gentleman overseer." ${ }^{15}$ In Bacon's vision, the mechanical arts were worthy of study primarily as the

13. Carl Mitcham and Eric Schatzberg, "Defining technology and the engineering sciences", in Anthonie MejJers (ed.), Philosophy of Technology and Engineering Sciences, Amsterdam, Elsevier/ North Holland, 2009, p.35.

14. See George Ovitt, Jr., "The cultural context of western technology: early Christian attitudes toward manual labor", Technology and Cultur, 27, n 3, 1986, p. 477-500; Birgit van den Hoven, Work in Ancient and Medieval Thought: Ancient Philosophers, Medieval Monks and Theologians and their Concept of Work, Occupations and Technology, Amsterdam, J. C. Gieben, 1996; Guy H. ALLARD, "Les arts mécaniques aux yeux de l'idéologie médiévale", in G. H. AllLard and S. Lusignan (ed.), Les arts mécaniques au Moyen Âge, Montreal, Bellarmin, 1982, p. 13-31.

15. Peter Dear, Revolutionizing the Sciences: European Knowledge and its Ambitions, 1500-1700, Princeton, NJ, Princeton University Press, 2009, $2^{\text {nd }}$ ed., p. 50. 
"fruit" of natural philosophy, or as material for natural philosophers to appropriate and systematize. ${ }^{16}$

This tension continued into the $18^{\text {th }}$ century, especially in Enlightenment encyclopedias of the "arts and sciences." Early Enlightenment encyclopedias devoted some space to the mechanical arts, but not until Diderot and D'Alembert's Encyclopédie did these arts receive focused attention. This encyclopedic treatment reflected in part a growing collaboration between artisans and men of letters, despite persistent aristocratic prejudice against the mechanical arts. Joel Mokyr terms this movement the "industrial enlightenment," though, as many critics have noted, there are serious problem with Mokyr's understanding of the relationship between formal knowledge and technical practice. ${ }^{17}$ Ursula Klein offers a better way to frame this collaboration, emphasizing the emergence of artisanal-scientific experts, social hybrids who were at home both among men of letters and skilled workers. ${ }^{18}$

Enlightenment authors explored the relationship between natural knowledge and productive activity in terms of a discourse of art and science. Perhaps the most famous example is Diderot's article on art in the Encyclopédie. ${ }^{19}$ But this discourse did not, however, succeed in transforming the scholarly understanding of the mechanical arts. Instead, the spread of the market economy, even though it weakened the traditional society of orders, also gave rise to new discourses that aborted a deeper reconceptualization of the art-science relationship.

\footnotetext{
16. For a critical assessment of Bacon's attitude toward the mechanical arts, see Romano NanNI, "Technical knowledge and the advancement of learning: some questions about 'perfectibility' and 'invention", in Claus ZitTel (ed.), Philosophies of Technology: Francis Bacon and His Contemporaries, Leiden, Boston, Brill, 2008.

17. Joel Mокуr, The Gifts of Athena: Historical Origins of the Knowledge Economy, Princeton, N.J., Princeton University Press, 2002, p. 34-41. For critiques of Mokyr, see Maxine BERG, "The genesis of 'useful knowledge", History of Science, 45, 2007, p. 127-130; Liliane Hilaire-PÉrez, "Technology as a public culture in the eighteenth century: the artisans' legacy", History of Science, 45, 2007, p. 135-153; William J. Ashworth, "The ghost of Rostow: science, culture and the British Industrial Revolution”, History of Science, 46, 2008, p. 249-274.

18. Ursula KleIn and Emma C. SpARY (ed.), Materials and Expertise in Early Modern Europe: Between Market and Laboratory, Chicago: The University of Chicago Press, 2010. See also Lissa Roberts, "Introduction [to section III]", in Lissa Roberts, Simon Schaffer and Peter Dear (ed.), The Mindful Hand: Inquiry and Invention from the Late Renaissance to Early Industrialisation, Amsterdam, Royal Netherlands Academy of Arts and Sciences, 2007, p. 189-195.

19. Eric Schatzberg, "From art to applied science", Isis, 103, n 3, 2012, p. 555-563.
} 
Two changes were key. First was the rise of fine arts as a clearly defined category, which in effect stripped aesthetic creativity from the mechanical arts. ${ }^{20}$ The second key change was the rise of industrial capitalism in the late $18^{\text {th }}$ century, when industrialists emerged as new allies for men of science. The result of this new alliance was a devaluation of the mechanical arts and a reassertion of the primacy of science though the concept of applied science. In a crude sense, the new discourses of applied science and fine arts made it harder for technology to become an academic discipline in the $19^{\text {th }}$ century. $^{21}$

Nevertheless, the Enlightenment did produce the first sustained attempt to create a discipline around the concept of technology, or rather die Technologie. Johann Beckmann's Anleitung zur Technologie (1777) proposed a discipline called Technologie devoted to the systematic description of handicrafts and industrial arts. Beckmann was a prominent figure in German Cameralism, a set of academic disciplines concerned primarily with state administration. With the Anleitung, Beckmann helped turn Technologie into a minor academic field, as German universities appointed professors of Technologie who taught courses in the subject. ${ }^{22}$

Yet Cameralist Technologie remained very different from $20^{\text {th }}$ century technology. According to Beckmann, Technologie was "the science that teaches the processing of natural products or the knowledge of handicrafts." 23 Cameralism was grounded in a natural-historical approach to knowledge that focused on classifying, not explaining. Beckmann's Technologie thus followed squarely in the tradition of Francis Bacon's proposal for a natural history of trades, a project realized in part by the Encyclopédie. But Beckmann did not share the Encyclopédie's democratizing spirit. For Beckmann and his followers, Technologie constituted knowledge not for the artisan but rather for officials in the royal courts who had administrative responsibilities related to artisanal trades. Technologie was therefore a

20. Larry Shiner, The Invention of Art: A Cultural History, Chicago, University of Chicago Press, 2001.

21. E. Schatzberg, "From art to applied science", op. cit.

22. Guido Frison, "Linnaeus, Beckmann, Marx and the Foundations of Technology. Between natural and social sciences: a hypothesis of an ideal type", History and Technology, 10, 1993, p. 141154.

23. "Technologie ist die Wissenschaft, welche die Verarbeitung der Naturalien, oder die Kentniß der Handwerke, lehrt.", Johann Beckmann, Anleitung zur Technologie, oder zur Kentniß der Handwerke, Fabriken und Manufacturen, Göttingen, Wittwe Vandenhoeck, 1780, $2^{\text {nd }}$ ed., p. 17. 
form of elite, rather than artisanal, knowledge, a theme that recurs repeatedly in the history of this concept. ${ }^{24}$ Yet this elitism was not inherent in the concept of technology as the science of the industrial arts. For example, a strong democratic spirit pervaded the 22-volume Dictionnaire technologique, which was produced by the French artisan-scholar Louis Sébastien Lenormand between 1822 and 1835. ${ }^{25}$

Cameralist Technologie was ultimately a dead end, in part because its approach was largely descriptive and taxonomic. Technologie in German lands gradually faded by the mid $-19^{\text {th }}$ century as Cameralist theories began to be viewed as passé. Neither German engineers nor social scientists made more than passing references to Technologie in the last third of the $19^{\text {th }}$ century. Technologie never disappeared, but it lost all of its theoretical significance with the decline of Cameralism. However, the presence of Technologie in the German university system helped keep the term alive, along with its cognates in other languages.

Why, then, didn't technology become a significant subfield in the emerging social sciences of the late-nineteenth and early twentieth centuries? During this era, economics, sociology, anthropology, and political science coalesced as academic disciplines. These disciplines arose at the height of the second industrial revolution, the period from roughly 1870 to 1930 that produced industrial modernity. ${ }^{26}$

Yet in none of these social sciences did technology become a significant area of scholarship. In economics, the new marginalist economics defined technology as outside the scope of economics. Talcott Parsons did the same for sociology, building on Weber's separation of Technik from Wirtschaft. Charles Beard flirted with the concept of technology in political science, but never developed it into a field of study. ${ }^{27}$

\footnotetext{
24. G. Frison, "Linnaeus, Beckmann, Marx", op. cit.

25. Joost Mertens, "Technology as the science of the industrial arts: Louis Sébastien Lenormand (1757-1837) and the popularization of technology", History and Technology, 18, 2002, p. 213.

26. Thomas P. Hughes, American Genesis: A Century of Invention and Technological Enthusiasm, New York, Viking, 1989; Dorothy Ross, The Origins of American Social Science, Cambridge, Cambridge University Press, 1991.

27. Eric Schatzberg, Technology: Critical History of a Concept, Chicago, University of Chicago Press, in press.
} 


\section{Technology as the science of the arts in American anthropology}

I now turn to my case study, technology in English-language anthropology. Of all the emerging social-science disciplines in the late $19^{\text {th }}$ century, anthropology seems the most likely discipline to adopt technology as a field in the human sciences. Since its $19^{\text {th }}$ century beginnings, anthropologists have taken artifacts, craft skills, and material culture seriously, although they did not describe these objects of study as technology. ${ }^{28}$ In fact, anthropologists and other social scientists of the era lacked an overarching concept that could encompass the full historical range of material practices and forms of knowledge that would later be classified as technology.

Nevertheless, in the last two decades of the $19^{\text {th }}$ century, anthropologists did tentatively embrace the definition of technology as a scientific field, the science of the "industrial arts." In the work of American anthropologists such as John Wesley Powell and Otis T. Mason, technology became one of the key subfields in the science of anthropology. Yet this subfield failed to thrive, in part because of its connection to evolutionary theories of society. In these theories, material culture served as a key marker of the evolutionary stages of savagery, barbarism, and civilization. However, as evolutionary theories went out of fashion with the rise of cultural anthropology in the United States and social anthropology in Great Britain, technology largely disappeared from anthropology's conceptual repertoire until the 1940 s.

In 1871, the British anthropologist E. B. Tylor, in his foundational work Primitive Culture, famously defined "culture or civilization ... in its wide ethnographic sense ... [as] that complex whole which includes knowledge, belief, art, morals, law, custom, and any other capabilities and habits acquired by man as a member of society". ${ }^{29}$ Art in this context referred to practical knowledge of all sorts, including numeracy. Art for Tylor did

28. The Oxford English Dictionary cites two apparent cases of anthropologist Richard Burton using technology the refer to the practical arts collectively in mid-century, but these are exceptions. C. T. Onions and James Augustus Henry Murray, A New English Dictionary on Historical Principles; Founded Mainly on the Materials Collected by the Philological Society, 10 vols., vol. 9, Oxford, Clarendon Press, 1919, p. 137.

29. Edward B. Tylor, Primitive Culture: Researches into the Development of Mythology, Philosophy, Religion, Art, and Custom, 2 vols., London, J. Murray, 1871, p. 1. 
not imply fine art, even though the aesthetic meaning of art was becoming increasingly widespread in English by this era. ${ }^{30}$

Tylor singled out the "industrial arts" in particular as one of the "principal criteria of classification" for assessing a culture's place on the scale of civilization. Furthermore, "mechanical invention" also provided "apt examples" of evolutionary development in culture, with new devices superseding the old in a clear sequence. In firearms, for example, the "clumsy wheel-lock" was replaced by the "more serviceable flint-lock" and then the "obvious modification" of the percussion cap. Such examples, he claimed, could be repeated "through the history of one art and instrument after another." Such sequences were so predictable that the anthropologist "can reconstruct lost history without scruple, trusting to general knowledge of the principles of human thought and action" to fill in the missing steps in the development of a technology. ${ }^{31}$

Tylor was not a pure evolutionist, however; he accepted that specific arts could spread geographically, just like biological species. ${ }^{32}$ In this way, the geographical boundaries of inventions could help determine the boundaries of a culture. In fact, argued Tylor, the "diffusion" of domesticated plants and animals often coincided with the diffusion of "corresponding art and knowledge." Thus the same causes that brought horses and wheat to the New World also brought firearms and iron hatchets. ${ }^{33}$

Despite what seems like a crudely linear understanding of technological change, Tylor never argued that the state of the arts determined the evolutionary stage of a culture. Other criteria were equally important, for example "moral and political excellence," but these were more difficult to assign on a scale of progress. ${ }^{34}$ In Primitive Culture, Tylor devoted far more pages to language, myth, religion, and ritual than to what would now be termed technology.

With regard to the history of concepts, Tylor clearly had no concept of technology or its equivalent, no overarching term that could embrace the

30. On this shift in the meaning of art, see L. SHINER, Invention of Art, op. cit.

31. E. B. Tylor, Primitive Culture, p. 23, 13-14, 56-58.

32. Jerry D. Moore, Visions of Culture: An Introduction to Anthropological Theories and Theorists, $4^{\text {th }}$ ed., Lanham, Md., AltaMira Press, 2012, p.7.

33. E. B Tylor, Primitive Culture, p. 7-8.

34. Ibid., p. 25. 
material aspects of culture. A variety of overlapping terms pepper his analyses, such as industrial arts, mechanical invention, material arts, and instruments. In his 1881 textbook, Anthropology, he devoted four chapters to the "Arts of Life." This category included tools, weapons, mills, wheeled transport, hunting, agriculture, dwellings, architecture, clothing, weaving, water transport, cooking, pottery, metals, and finally commerce. Aside from commerce, this motley collection clearly fits within the present-day scope of technology. Tylor excludes fine arts from these chapters, placing them in a separate chapter on the "Arts of Pleasure," where Tylor discussed poetry, music, dance, sculpture, painting, and games. ${ }^{35}$

Like Tylor, the American evolutionary anthropologist Lewis Henry Morgan also used technology as a key measure of human progress, and, like Tylor, Morgan never used the term itself. Rather than technology, Morgan used the phrase "Arts of Subsistence" as the title of a key chapter in his most important work, Ancient Society, published in 1877. Drawing on the Darwinian idea of a struggle for existence, Morgan grounded social evolution in the gradual mastery of humans over their environment. Morgan stressed the role of settled agriculture and the working of domesticated animals to supplement human labor, for example in the "new art" of plowing. Morgan subdivided the traditional eras of savagery and barbarism, given each a lower, middle, and upper period, distinguished primarily by the means of subsistence and other forms of material culture. ${ }^{36}$

This part of Morgan's theory was, according to Leslie White, "materialistic, technological, and ecological." It was this aspect of Morgan's work that made Ancient Society a favorite of Marx and Engels. Engels declared, rather improbably, that Morgan had "discovered anew the materialistic conception of history." In fact, as White noted, Morgan's anthropology is "predominately psychological, or ideological, concerned with the growth of ideas." ${ }^{37}$ Morgan's interest in technology was significant but secondary to his work on social institutions, most importantly systems of kinship,

35. Edward B. TyLOR, Anthropology: an introduction to the study of man and civilization, New York, D. Appleton and Company, 1881.

36. Lewis H. Morgan, Ancient society: or, Researches in the Line of Human Progress from Savagery Through Barbarism to Civilization, Chicago, C.H. Kerr, 1877, p. 18, 26; Leslie A. White, "Introduction", in Lewis H. Morgan (ed.), Ancient Society, Cambridge, Mass., Belknap Press of Harvard University Press, 1964, p. xxiii.

37. L. A. White, "Introduction", op. cit., p. xx, xxxiii. 
which Morgan classified under the "idea of government." In this respect, Morgan and Tylor were also alike, acknowledging a key role for the "arts of life" while relegating them to a subordinate position in their evolutionary schemes.

Where was the concept of technology in all this? As I remarked above, technology remained a specialized term in the $19^{\text {th }}$ century, but it was hardly unknown, and almost invariably defined as the science of (or discourse about) the arts. Such a term would have been ideal for designating the Tylor's study of "arts of life." The absence of the technology in almost all early anthropological research is a testament to its relative obscurity.

Nevertheless, technology briefly became a central concept in American anthropology in the 1880s, serving for a time as one of the key subdivisions in American evolutionary anthropology. But technology faded as an anthropological concept by the end of the century. Not until the 1940s did technology return as a key term in anthropology, most prominently in the work of the evolutionary anthropologist Leslie White and the Marxist archeologist Vere Gordon Childe. ${ }^{38}$

It was John Wesley Powell, the famous explorer of the American West, who first proposed technology as one of the fundamental divisions of anthropology. In 1879 Powell established the U.S. Bureau of Ethnology in Washington, D.C., as part of the Smithsonian Institution. ${ }^{39}$ That same year, Powell also helped found the Anthropological Society of Washington, which became a center of academic anthropology in the United States. The original constitution of the society, adopted in 1879, established the four main branches of the science of anthropology. These were Archaeology, Somatology, Ethnology, and Philology. Technology was absent from this founding document. Yet just three years later, the society's constitution was amended with a new set of fundamental branches: Somatology, Sociology, Philology, Philosophy, Psychology, and Technology. Although

38. Vere Gordon CHILDE, "Archaeological ages as technological stages", Journal of the Royal Anthropological Institute of Great Britain and Ireland, 74, $\mathrm{n}^{\circ}$ 1/2, 1944; Leslie A. White, "Energy and the evolution of culture", American Anthropologist, 45, n 3, 1943.

39. Donald Worster, A River Running West: The Life of John Wesley Powell, New York, Oxford University Press, 2001, p. 384. 
no logic for this reorganization was given, in effect it replaced archeology with technology. ${ }^{40}$

The Anthropological Society's embrace of the term technology almost certainly came from Powell. In 1882, he gave an address in Washington at the opening session of a meeting of the American Institute of Mining Engineers. Powell, who had just become director of the U.S. Geological Survey, discussed the close relationship between the science of geology and the practice of the mining engineer. "In this field, science and art go hand in hand," he declared. Mining engineers, as "scientific artisans," worked together "for the promotion of knowledge and the development of technology." Historians, he insisted, focused too much attention on politics and wars, when in fact, "technology has done more for mankind than sociology, institutions of art more than institutions of government." Technology and science each gave birth to the other "in alternating generations" that "multiply to bless mankind." ${ }^{41}$

Powell's address was an after-dinner speech singing the praises of American enterprise, not an academic paper. By 1882, such praise of progress in science and industry had been standard rhetoric in the United States for over half a century. ${ }^{42}$ Yet Powell's use of the term technology was rather unusual, especially in connecting the term to the progress of civilization. I have found no comparable rhetoric in English before this moment, or in fact for the remainder of the $19^{\text {th }}$ century. ${ }^{43}$

Yet Powell was not using technology to refer to the artifacts and practices of material culture. Instead, Powell was sticking to the $19^{\text {th }}$ century definition of the term as a field of study, a fact that he made clear in speech he gave to the Anthropological Society the following year. In this speech, Powell listed and defined each of main branches of anthropology, including "technology,

40. John Wesley Powell, "Historical notice", Transactions of the Anthropological Society of Washington, 1, 1882, p. 6, 7, 13-14.

41. John Wesley Powell, "Address of Major Powell", Transactions of the American Institute of Mining Engineers, 10, 1881-1882, p. 232-236.

42. John F. Kasson, Civilizing the Machine: Technology and Republican Values in America 17761900, Middlesex, England, Penguin Books, 1977.

43. Similar but more ambiguous language is found in Jacob Bigelow, An Address on the Limits of Education, Read before the Massachusetts Insitute of Technology, November 16, 1865, Boston, E.P Dutton, 1865. Worster misinterprets Powell's use of technology in the present-day meanings. D. Worster, A River Running West: The Life of John Wesley Powell, op. cit., p. 384. 
or the science of the arts." For Powell, art and industry remained the fundamental concepts denoting material culture; technology merely denoted the subfield of anthropology that focused on these activities. ${ }^{44}$

Still, Powell's usage had the potential to make technology into an accepted field within the social sciences. But nothing of the sort occurred. Instead, in 1887 a young German scholar, a recent arrival in the United States, launched a broad attack on the dominant evolutionary approach in anthropology, and in particular on the link between the useful arts and the level of civilization. This scholar was Franz Boas, one of the founders of cultural anthropology.

Boas published his first critique of American anthropology in an exchange of letters in Science, the journal of the American Association for the Advancement of Science. His attack focused on Otis T. Mason, an anthropologist at the Bureau of Ethnology whose work focused on the useful arts. Mason did two things that offended Boas. First, Mason argued for independent invention, claiming that similarities among technologies did not necessarily imply a connection among the peoples who possessed them. ${ }^{45}$ Second, Mason, as curator of ethnology in the National Museum in Washington, chose to display ethnographic artifacts in functional groups, such as textiles or pottery. ${ }^{46}$ In his attack on Mason, Boas did not directly dispute the first point about independent invention, but rather claimed that nothing meaningful could be said about ethnographic artifacts stripped of their context. This first objection led Boas to reject the functional arrangement of artifacts that Mason used in the National Museum. Instead, Boas argued for arranging artifacts according to their "surroundings," that is, their cultural and geographical contexts. ${ }^{47}$

44. John Wesley Powell, "Human evolution; annual address of the President, J. W. Powell, Delivered November 6, 1883", Transactions of the Anthropological Society of Washington, 2, 1883, p. 181182.

45. Otis T. Mason, "Resemblances in arts widely separated", The American Naturalist, 20, 1886, p. 246-251.

46. This type of arrangement is also reflected in Otis T. Mason, The Origins of Invention: A Study of Industry Among Primitive People, London, Walter Scott, 1895.

47. Franz BoAs, "The occurrence of similar inventions in areas widely apart", Science, 9, 1887, p. 485-486; id., "Museums of Ethnology and Their Classification", Science, 9, 1887, p. 587-589. 
Mason replied politely, arguing that the two approaches were not incompatible, but simply different ways to view the same material. ${ }^{48}$ But in a second letter, Boas would admit to no common ground with Mason. The problem with Mason's system, argued Boas, was that "the leading idea is technology." As a principle of classification, Boas insisted that technology provided only a one-sided and "limited" view of the field. He concluded that it was "not justifiable to make technology, in the sense Professor Mason does, the basis of arranging ethnological collections." ${ }^{49}$

Historians of American anthropology portray this exchange of letters as the beginning of a fundamental shift from an evolutionary to a diffusionist paradigm, a shift largely completed by the turn of the century. ${ }^{50}$ But this exchange only took on significance in hindsight. The arguments Boas made were actually quite muddled. He confused reasoning by analogy with generalization, and he endorsed a simplistic inductivist understanding of science. ${ }^{51}$ Boas in effect downplayed any attempt to generalize based on comparative methods. "In ethnology all is individuality," he insisted. More important for my purposes is Boas's clear hostility to the concept of technology in general, and his opposition to Mason's project to develop a general understanding of the industrial arts. Boas argued that the purpose of anthropology is to understand "ethnological phenomena" as shaped by "surroundings," that is physical geography and social institutions. But Boas did not distinguish material artifacts from any other ethnological phenomena. In other words, he saw nothing special about technology, and hence no need for a science of the arts. Instead, Boas believed that ethnological collections should be used to show that civilizations were the product of geography and history. ${ }^{52}$

With the rise of Boasian anthropology in the United States after 1900, technology disappeared as an organizing concept in anthropology. Boas

48. Otis T. Mason, "The occurrence of similar inventions in areas widely apart", Science, 9, 1887, p. $534-535$.

49. F. BoAs, "Museums of ethnology and their classification", op. cit., p. 588-589.

50. J.D. Moore, Visions of Culture: An Introduction to Anthropological Theories and Theorists, op. cit. p.31, 36-39; George W. STOCKING, "Introduction: the basic assumptions of Boasian anthropology", in George W. Stocking (ed.), The shaping of American anthropology, 1883-1911; a Franz Boas Reader, New York, Basic Books, 1974, p. 1-5.

51. John Buettner-Janusch, "Boas and Mason: particularism versus generalization", American Anthropologist, 59, n², 1957, p. 318-324.

52. F. Boss, "Museums of ethnology and their classification", op. cit., p. 589. 
barely used the term after the 1880 s, even though he remained a prolific author right up to his death in 1942. None of his students took up the term either, even as its meaning shifted after World War I as a result of Thorstein Veblen's influence. ${ }^{53}$ The term did not disappear completely in anthropology, but American anthropologists abandoned any attempt to generalize about technology as a core component of culture. In Mason's 1895 Origins of Invention, for example, the term is almost entirely absent, although Mason did create a handful of neologisms around the root techn-, none of which caught on. ${ }^{54}$ Powell himself, who died in 1902, only occasionally used the term after his exchange with Boas, most prominently in an 1899 article titled "Technology, or the Science of Industries." But technology was only mentioned once in the text of the article. ${ }^{55}$ In any case, Powell was near the end of his life and his influence was waning; this article was ignored by subsequent scholars.

Only in the 1940s did Leslie White revive the concept of technology in anthropology. ${ }^{56}$ But White embraced a crudely determinist understanding of the relationship between technology and cultural change, an understanding that was in many ways less nuanced than the views of Otis Mason over half a century earlier.

We should not, however, attribute to one man this failure to embrace technology as a conceptual category. Although the details differ, a similar story can be told about other disciplines in the social sciences. Sociologists also toyed with technology as a core category, only to reject it. Lester Ward, one of the founders of American sociology, worked under John Wesley Powell at the Bureau of Ethnology in the 1880s. His Dynamic Sociology of 1883, one of the first major American works in sociology, made no use of the concept of technology. ${ }^{57}$ Even after Thorstein Veblen introduced the concept with its new meaning into American social sciences, sociologists did nothing with it. Talcott Parsons, for example, explicitly excluded

53. E. Schatzberg, “Technik Comes to America.", op. cit.

54. O.T. Mason, Origins of Invention, op. cit., p. 8, 78.

55. In this article, Powell no longer used the term art in its broad sense, instead distinguishing sharply between art in its aesthetic sense and industry as practical activity. J.W. Powell, "Technology, or the science of industries", p. 319-349.

56. L.A. White, "Energy and the evolution of culture", op. cit., p. 335-356.

57. Lester Frank WARD, Dynamic sociology, or Applied social science, New York, D. Appleton and company, 1883. 
technology as a topic of interest to sociology in his 1937 work Structure of Social Action. This book represented one of the first attempts to ground American sociology in recent Continental theory. Parsons' exclusion of technology is even more remarkable given his early exposure to Veblen's ideas while an undergraduate at Amherst College. ${ }^{58}$ American sociologists only took up the topic of technology in the late 1930s, mainly through the work of William F. Ogburn, whose conception of technology was almost laughable in its crude determinism. ${ }^{59}$

In the discipline of economics, a similar story unfolded. Before history was stripped from economics, the emerging field did toy with the concept of technology. Under the influence of Veblen, who himself was influenced by the German Historical School, Institutional economists tried to bring technology within the scope of economics, but not systematically. ${ }^{60} \mathrm{With}$ the triumph of the neo-classical paradigm, technology was once again pushed to the margins of the field. ${ }^{61}$

Although my focus here has been on English language sources, primarily American, similar arguments apply in other major European languages. In German, I have found no serious attempt to formulate a theory of technology in the social science under the heading of Technologie. Most discussion of technological topics were framed around Technik, and even then few social scientists attempted to develop a theory about the subject. ${ }^{62}$ Despite significant philosophical discourse about Technik in the Weimar

58. Talcott Parsons, The Structure of Social Action: A Study in Social Theory with Special Reference to a Group of Recent European Writers, New York, McGraw-Hill, 1937, p.770; Charles Camic, "Reputation and predecessor selection: Parsons and the Institutionalists", American Sociological Review, 57, 1992, p. 421-445.

59. William Fielding OGburn, "Technology and governmental change", Journal of Business of the University of Chicago, 9, 1936, p. 304.

60. C. E. Ayres, "Moral confusion in economics", International Journal of Ethics, 45, 1935, p. 170199.

61. See Paul A. David, Technical Choice, Innovation and Economic Growth: Essays on American and British Experience in the Nineteenth Century, London, Cambridge University Press, 1975.

62. One of the most detailed discussions of Technik in German-language social sciences is Werner Sombart, "Technik und Kultur", Archiv für Sozialwissenschaft und Sozialpolitik, 33, 1911. For an early overview of this literature see Max SchneIder, Uber Technik, technisches Denken und technische Wirkungen”, Dissertation, Friedrich-Alexanders-Universität, Erlangen, 1912. There is also a very large philosophical discourse of Technik in German, much of it by engineers. See C. Miтcham, Thinking Through Technology, op. cit. 
era, this topic never coalesced into a coherent field, especially in contrast to the philosophy of science.

In French, the idea of la technologie as a scientific field was considered seriously well into the $20^{\text {th }}$ century. Even more so than in German, there is a rich scholarly literature around la technologie and la technique that cuts across multiple social sciences. I can do little more than gesture toward this literature here. The term technologie was resurrected in the late- $19^{\text {th }}$ century by Alfred Espinas, who wanted to develop a general science of technology. A number of scholars, including Marcel Mauss, André-Georges Haudricourt, and Francois Sigaut all advocated for technologie as a field within the social sciences. ${ }^{63}$ These scholars were building on a strong tradition in French social sciences that focused on the study of les techniques. Nevertheless, la technique, not la technologie, has remained the core concept among these scholars. Unfortunately, these French authors have been neglected by Anglophone scholars, in part because the distinction between technique and technologie does not translate properly into English. In the end, what accounts for the repeated failure of social scientists to take technology seriously as a disciplinary category? Although one can identify immediate causes in each case, something more fundamental is at work here, namely a deeply ingrained prejudice among intellectuals that favors works of the mind over works of the hand, theory over practice, inspiration over technical skill, the liberal over the banausic, elite culture over mundane culture, and so on. Although these dichotomies do not overlap precisely, they are all manifestations of the same general tendency that runs throughout the history of intellectual culture. Put crudely, these prejudices reflect status anxieties among intellectuals, whose class insecurities are reflected in their choice of subject matter. But there's an even deeper problem at work here, namely the tacit dimension of technical knowledge, the fact that most technical skills cannot be reduced to formal, propositional

63. François Sigaut, "La technologie de l'agriculture: terrain de rencontre entre agronomes et ethnologues", Etudes rurales, 59, 1975, p.103-111; André-Georges HaudricourT, La technologie, science humaine: recherches d'histoire et d'ethnologie des techniques, Paris, Éditions de la Maison des sciences de l'homme, 1988; Alfred Victor Espinas, Les origines de la technologie, Paris, Félix Alcan, 1897; Jan Sebestik, "Les commencements de la technologie. Postface/préface", Documents pour l'histoire des techniques. Nouvelle série, 14, 2007, p. 123-133. 
Why is there no discipline of technology in the social sciences?

knowledge. ${ }^{64}$ Why would intellectual want to grapple with a form of knowledge that refuses to give up its secrets to mere words?

\section{Author}

Eric Schatzberg is professor of history and chair of the School of History and Sociology at the Georgia Institute of Technology. His book, Technology: Critical History of a Concept, will be published by University of Chicago Press in October 2018. His current research examines critiques of technology in the post-WWII era. Contact: eric.schatzberg@hsoc.gatech.edu

64. H. M. Collins, Tacit and Explicit Knowledge, Chicago, University of Chicago Press, 2013. 